\title{
Meaningful learning in business through serious games
}

\author{
Ana Cristina Urquidi Martín(D), Carmen Tamarit Aznar(iD) \\ Universidad de Valencia (Spain) \\ ana.c.urquidi@,uv.es, carmen.tamarit@,uv.es
}

Received November, 2016

Accepted October, 2017

\section{Abstract}

Purpose: The requirements of a business executive include the talent and creativity to solve problems and adapt to continuous changes presented by the economic and social environment. However, the university does not often prepare students in these skills. Businesses simulations are didactic tools in which participants assume a role and make decisions which affect the results of the company. This paper aims to provide empirical evidence on the effectiveness of business simulations in university teaching.

Design/methodology: We have implemented business simulations in a course in the College of Economics at the University of Valencia, during the 2015-2016 academic year. Questionnaires were used to collect the students' opinions about this educational tool.

Findings: Students are motivated and concentrated during all activities, which has promoted cooperation and/or competition. They therefore perceive these simulations as a useful tool to acquire skills, especially those linked to decision making, problem solving, and the analysis of business information.

Research limitations/implications: No common theoretical framework exists in the literature for measuring the results of the learning. This study investigated the influence of three subjective variables. In this sense, future research could expand on the number of variables and include objective data. 
Practical implications: Improvement of the educational process.

Social implications: Students receive a comprehensive education, including a set of social behaviors and cognitive, psychological and sensory skills, which enable them to respond successfully to new demands in the labor market.

Originality/value: Much has been written about the usefulness of simulations in education, but there is little empirical evidence on the learning outcomes that result from their use.

Keywords: Simulations, Higher education, Educational innovation, Active learning

Jel Codes: A22

\section{Introduction}

Towards the end of the 20th century, the instructional model was primarily based on master classes in which the role of the student was limited to taking notes and then memorizing them, expanded upon by the recommended bibliography through repetitive reading, eventually culminating in an evaluation in the form of a test. This is currently changing. There is a desire to place students in the center of the teaching-learning process, focusing studies on the competencies that new graduates must have, building on the students' know-how, initiative and autonomous learning, as indicated by the Dublin descriptors (Joint Quality Initiative, 2004).

These transformations imply a change in the educational paradigm, from a model based almost exclusively on knowledge transfer to another supported by the flexibility of the system to achieve the comprehensive training of individuals. Currently, the intent is not to educate subjects to be accumulators of knowledge, rather people who are actively involved in their own educational process, learning to recognize how much information they need and when. To accomplish this, greater emphasis is placed on the development of skills and abilities, in short, with the intent that the individual learns to think and to perform (Durham \& Mckinnon, 2006).

Business simulations are tools that are intended to replicate the characteristics and behaviors typically found in a company. Participants must take on challenges that reproduce simplified models of reality. The person, individually or in a group, puts into practice their skills through experiential learning, and 
at the same time experiences the decision-making process, tackling real-life problems, all this in a riskfree environment, since the setting where this takes place is safe, and what is more important, if the result is erroneous, there is stimulation to try again. It is based on this game, which involves trial and error, where the greatest learning occurs (Axerod, 2006; Bratley, Fox and Schrage, 1987; Fitó-Bertran, Hernández-Lara \& Serradell-López, 2014; Shannon \& Johannes, 1976).

According to the above reasoning, business simulations can be a useful tool for active learning by university students, since they introduce them to real-life situations and the students are required to actively build or reconstruct knowledge. However, it is difficult to state whether the simulations really meet the requirements and expectations of students, and it is also difficult to determine whether they allow the set learning objectives to be met.

For this reason, the main motivation of this study is to empirically validate the benefits for learning derived from the use of business simulations in the classroom. To do this, said simulations have been implemented in a course forming part of a degree program in the College of Economics at the University of Valencia during the 2014-2015 academic year, with the aim of having the students acquire and develop skills and abilities that meet the curricular needs and the requirements demanded by the business world and society.

\section{Simulation and learning}

Simulation and learning are two closely related concepts in the educational process. From a purely instrumental perspective, we can say that most of the learning activities are based on simulated entities. Examples would be the resolution of a case of warehouse management or the calculation of a company's annual budget. The instructor and student are working with models and cases that have been adapted from reality at all times, since the lecturer rarely leaves the classroom and accompanies the students into the real world to explain and demonstrate theories, laws or hypotheses.

The term simulation has been constrained in the present work, referring only to those generated by computer programs, excluding other areas with a very similar application to the learning process, such as dramatizations, role-playing activities, laboratory activities, case methods or practical case studies.

According to the recommendations by the Association to Advance Collegiate Schools of Business (2007), a business simulation must have the following characteristics: 
- It must consider ethical aspects and implications: participants must be able to recognize and analyze different ethical problems presented either directly or indirectly.

- It must provide mechanisms for the communication of all aspects used during the business game.

- It must facilitate critical analysis: participants must be able to study the conditions of the competitive environment and make decisions using theoretical models, and know the tools that facilitate the choice of appropriate decisions.

- It must promote group work: it must encourage participants to establish systems of collaboration in order to achieve the group's objectives.

- It must provide a global perspective that enables the participants to recognize opportunities and the risks associated with the concurrence of different cultures, market structures, currencies, etc.

Thanks to all of the above, simulations favor in-depth learning from two differentiated areas. First of all, they form a bridge between theory and practice, giving students the opportunity to acquire experience through participation and learning thanks to the actions they take, since participants will deal with a real-life model and must think and act by making decisions that lead them to reach their final objective (Armstrong \& Hird, 2009; Witkin et al., 1977).

Secondly, the simulation process reinforces learning through the subsequent analysis of the results obtained. After the simulation has been completed, the reasoning behind the different decisions made by the students and their results permit reflection and the development of creative, critical thought and learning about problem solving (Andreu-Andreu \& García-Casas, 2014; Arellano, Hine and Thilmany, 2001; Kennedy, Fisher \& Ennis, 1991). 


\section{Research design}

\subsection{Population and data collection}

In studies of this type, it is necessary to take into account the characteristics of the participants, since this can influence the values obtained for the variables being studied. In this regard, the target population is students in the second year of Business Administration studies in the College of Economics at the University of Valencia, during the 2015-2016 academic year. The sample consists of 58 students registered for the Cost Accounting course, of whom $72 \%$ were women and $28 \%$ men. All were between 19 and 23 years of age and 100\% owned a mobile phone and a computer.

\subsection{Variables}

Since there is no theory or model considered universal in the literature to measure the results of learning (Sørensen, 2010), many authors have proposed different variables based on which to determine the effectiveness of the simulations in the teaching-learning process, as well as scales that permit measuring said variables (Blunt, 2009; Freitas \& Jarvis, 2007; Garris, Ahlers \& Driskell, 2002; Gresse von Wangenheim, Savi \& Ferreti Borgatto, 2012; Guillén-Nieto \& Aleson-Carbonell, 2012; Wrzesien \& Alcañiz, 2010; Yusoff, Crowder \& Gilbert, 2010).

This work studies three of these variables: evaluation of the experience, learning and the development of critical thinking.

- Evaluation of the experience: the students feel motivated by a class taught using a business simulator. This motivation helps generate interest in the learning or for the activities that contribute to it. It is necessary to bear in mind that interest can be acquired, maintained or increased according to both intrinsic and extrinsic elements. Works such as those by Annetta, Minogue, Holmes and Chen (2009), Sitzmann (2011) and Wouters, Van Mimwegen, Van Oostendorp and Van der Spek (2013) conclude that by using simulations in the teachinglearning process, the intrinsic motivation of students increases, and they are thus more committed to the process and learn more than with the use of traditional teaching methods. However, in order to maintain and increase motivation, both the students' knowledge of computers and theoretical knowledge must be taken into account, as well as the simplicity of the simulation (Moizer, Lean \& Towler, 2009; Sutcliffe, 2002), since the complexity can permit a 
more realistic simulation, but it can also reduce the students' capacity to learn if they are overwhelmed by it. As a result, students will be more motivated with a learning activity that they perceive as a challenge appropriate for their skill level, so that they have a certain level of control over the result of the activity (Córdova \& Lepper, 1996; Pekrun, Goetz, Daniels, Stupnisky \& Perry, 2010).

- Learning: The impact of a simulation on cognitive human development stems from the fact that it permits students to learn in an active manner. Among the main advantages of using simulators as educational tools, Keys and Wolfe (1990) highlight:

- The interaction, which provides quick, specific and coherent feedback on the decisions made. Every action has a reaction, and therefore students can verify the consequences of their decisions.

- They facilitate the study of situations which, due to their cost, danger, size or distance, are not normally accessible to students; thus the risk of the decision made or the cost of a poor decision does not prevent students from experimenting and therefore learning from their own experience.

- They stimulate the student's hypothetical/deductive mechanisms, permitting discovery learning. This active participation in their own learning permits a profound internalization of the material being learned.

In addition, the research by Antonietti, Rasi, Imperio and Sacco (2000) and Lee, Wong and Fung (2010) shows that students perceive cognitive benefits, such as increased memorization and improved comprehension; a global overview is also possible of topics that have been dealt with separately, as well as the application of theoretical concepts.

Consequently, business management games constitute an especially important teaching method, given that they make it possible to present real circumstances to students that they will encounter in their future business activity (Escobar \& Lobo, 2005).

- Critical thinking: is a way of thinking about any topic, content or problem, but that must always be useful, reasoned and aimed at achieving an objective (Halpern, 1996). It refers to thought that participates in problem solving, the formulation of inferences, the calculation of probabilities and decision-making. Any educational method is valid for the acquisition and comprehension of information, but for other objectives, such as the development of critical 
thought and autonomous learning, student-centered methods are the most effective. For it to be successful, not only must students be able to access information in an efficient manner, they must also be able to evaluate it judiciously and competently and know how to use it accurately and creatively to solve problems.

\subsection{Teaching methodology used}

Given that the main objective of the degree program in Business Management and Administration (BMA) is to train professionals capable of performing management, advisement and evaluation-related tasks in productive organizations, and said tasks can be performed globally within the organization or in any of its functional areas (production, human resources, finance, marketing, investment, administration or accounting), graduates must be aware of the link between all these functional areas and the overall objectives of the production unit and between these objectives and the global economic context, as well as be able to contribute though their activity to the smooth operation and improved results. Specifically, they must know how to identify and anticipate opportunities, assign resources, organize information, select and motivate personnel, make decisions, reach the proposed objectives and evaluate the results.

For this reason, an application was sought that would make it possible to put into practice the skills being developed in the BMA program. The Platform wars. Simulating the Battle for Video Game Supremacy simulation was selected, developed by the Massachusetts Institute of Technology (MIT) for business management in competitive environments (Sterman, 2014).In it, participants take part in the senior management of a company and must establish a long-term strategy and make decisions based on financial information of both a qualitative and quantitative nature.

The simulation is designed to be highly educational in the area of business management, since it is a dynamic system oriented toward specific problems that arise in markets with cross externalities, where students must control fundamental variables related to real-life business situations, such as market potential, production capacity and volume, fixed and variable costs, contribution margins and economic and financial profitability.

Players act on three variables: the sales price of their product: the console, number of initial video games and the cost of video games compatible with the company's product, in such a way that their interpretation, their interrelationship and the results obtained based on these variables are easily 
observable. Accordingly, the result obtained (profit or loss) permits reflection, analysis and interpretation by the students, which proves to be very educational.

Decision making in the game is accompanied by analysis and interpretation of the results obtained in order to define the strategy followed and make the next decision. The system immediately provides the results following each decision, both graphically and in numeric form, in order to facilitate their analysis and interpretation; this information permits students to define, vary or confirm the strategy followed so far and to make the next decision.

While it is not necessary, alliances are formed between classmates and work groups are created. Before each decision, they ask questions of one another and share and explain information (informally and spontaneously). The first decisions are made in small groups or pairs, but once the students are immersed in the game, work teams clearly emerge.

This occurs not only for reasons of market positioning, but also because the rest of the teams become their competition. In this case, it was decided to permit these alliances, because while the objective was not to promote team work, it was considered important for students to develop this competency and it is an effective manner to improve communications between peers and leadership.

The winning and losing teams explain their strategy, the reason behind their decisions and how the results have evolved. Since the information about the decisions made and the results obtained is known by the instructor (provided by the system), he or she can specify, expand on or emphasize any aspects deemed necessary, especially with regard to the learning objectives and the purpose of the activity.

Factors have been taken into account that condition the effectiveness of the simulations as an effective learning tool (Urquidi Martín \& Calabor Prieto, 2014):

- the objectives have been clearly explained from the beginning of the activity;

- the simulation has been a valid representation of reality, since it is based on the launch of Sony's PlayStation 3, which obligates the participants to establish the philosophy, objectives and strategies of the company, where success or failure depends on the decisions they make, thus promoting exploratory learning skills;

- the simulation interface has enabled communication between humans and the computer. Its menus and windows are easy to read and understand, permitting the students to understand and interpret the results. 
Accordingly, the students were guided throughout the experience and provided support and assistance, answering their questions and encouraging feedback (Martínez-Argüelles, Plana, Hintzmann, Batalla Busquets \& Badia, 2015; Mayer \& Johson, 2010; Yusoff et al., 2010).

Once the activity was finished, the survey was distributed to the students, who completed it on a voluntary and anonymous basis. The questionnaire was developed based on a review of the relevant literature, and was structured into four blocks, according to what was intended to be measured, as is shown in Table 1.Given that the purpose of the entire study is for its items to indicate the essential elements that are attempted to be measured, once the questionnaire was developed, it was reviewed by experts on the topics, who evaluated the importance that each of the items had in the phenomenon that was intended to be observed. The experts also considered the clarity and accuracy of the items and modified those that could be difficult to measure or interpret based on the theoretical concept, or that might initially seem confusing, redundant or ambiguous, as indicated by Nunally and Bernstein (1994)

Different formats have been used according to the characteristics of the concepts or the information needs that existed. The first block collected data for classification purposes: gender, age, degree program and technology tools the student owned. An additive 5-point Likert-type scale was used for the questions in the following blocks (II, III, IV), according to which a minimum score of 1 point represented a response of strongly disagree with the item statement, 2 points for slightly agree with the statement, 3 points for a neutral response with regard to the statement, 4 points for a response of agree with the statement, and 5 points for a response of strongly agree, with there also being a does not know/chooses not to respond option.

\section{Analysis of the results}

Given that the reliability and validity of the constructs can change according to the theoretical model in which they are applied, the psychometric properties of the scales must be checked within the very model that is intended to be verified (Chin \& Marcolin, 1995). Therefore, before the model is evaluated, it is necessary to evaluate whether the constructs developed correctly measure the variables observed. It is therefore necessary to study the reliability of the individual items and the validity of the constructs. 


\begin{tabular}{|l|l|l|}
\hline Aspects addressed & \multicolumn{1}{|c|}{ Objective } & \multicolumn{1}{|c|}{ Source } \\
\hline $\begin{array}{l}\text { Block II: } \\
\text { Evaluation of the } \\
\text { experience } \\
\text { 8 items })\end{array}$ & $\begin{array}{l}\text { To find out the motivation of the participants } \\
\text { with regard to this activity, given the } \\
\text { importance of motivational factors in the } \\
\text { teaching-learning process. }\end{array}$ & $\begin{array}{l}\text { Adapted from: } \\
\text { Hamari, Shernoff, Rowe, Coller, } \\
\text { Clarke and Edwards (2016), } \\
\text { Huang (2011), } \\
\text { Gresse von Wangenheim et al. } \\
(2012)\end{array}$ \\
\hline $\begin{array}{l}\text { Block III: } \\
\text { Learning }\end{array}$ & $\begin{array}{l}\text { To find out the results perceived by the } \\
\text { participants in terms of the use of business } \\
\text { simulators for the improvement of their } \\
\text { learning process. }\end{array}$ & $\begin{array}{l}\text { Adapted from: } \\
\text { Antonietti et al.(2000) }\end{array}$ \\
\hline $\begin{array}{l}\text { Block IV: } \\
\text { Critical thinking } \\
\text { (7 items) }\end{array}$ & $\begin{array}{l}\text { To assess the acquisition of competencies } \\
\text { centered on obtaining information more } \\
\text { efficiently or improving the problem solving } \\
\text { process. }\end{array}$ & $\begin{array}{l}\text { Adapted from: } \\
\text { Bell and Loon (2015), } \\
\text { Irani, Rudd, Gallo, Ricketts, } \\
\text { Friedel and Rhoades (2007) }\end{array}$ \\
\hline
\end{tabular}

Table 1. Measurement scales

The Cronbach's alpha coefficient was used to measure the reliability of the scale and check the internal consistency of all the indicators. The items analyzed demonstrated good psychometric behavior in the adaptation and validation study, with reliability values between 0.71 and 0.83 in the different dimensions.

Next, an exploratory factor analysis with VARIMAX rotation was carried out in order to identify the underlying structure of the items to determine the factor structure of the scale and which items could be eliminated for having insignificant loadings or for loading on an inappropriate factor (Bontis, 1998). The analysis is adequate, since the KMO statistic has a value of 0.856 , and the significance associated with Bartlett's sphericity test is 0.000 .

The rotated component matrix, as shown in Table 2, reveals the existence of four factors, with eigenvalues higher than 1 and an explained variance of $72.118 \%$ :evaluation of the experience, active learning, cognitive benefits derived from the simulation and the development of critical thinking. Each of the items loads on the factor that corresponds to it and all the factor loads are greater than 0.5 , so it is not necessary to eliminate any of the items. 


\begin{tabular}{|c|c|}
\hline Items & Factor loads \\
\hline \multicolumn{2}{|l|}{ Evaluation of the experience (Cronbach's alpha $=0.83$ ) } \\
\hline I have been completely concentrated on the simulation. & 0.512 \\
\hline The simulation captured my attention from the very beginning. & 0.799 \\
\hline I would recommend this activity to my classmates. & 0.672 \\
\hline The simulation moved along at the right pace. & 0.669 \\
\hline The contents are connected to other knowledge I already had. & 0.523 \\
\hline The tasks are not too easy or too difficult; they pose a challenge. & 0.708 \\
\hline I was convinced that I was learning. & 0.667 \\
\hline It is easy to understand and to use. & 0.557 \\
\hline \multicolumn{2}{|l|}{ Active learning experience (Cronbach's alpha $=0.79)$} \\
\hline It allows me to be more perceptive and active in my learning process. & 0.544 \\
\hline I can have more control over my learning. & 0.678 \\
\hline I can learn at my own pace. & 0.514 \\
\hline \multicolumn{2}{|c|}{ Cognitive benefits derived from the simulation experience (Cronbach's alpha $=0.76$ ) } \\
\hline It boosts my memorization process. & 0.762 \\
\hline It helps give me an overview of the company. & 0.656 \\
\hline It lets me reflect on the consequences of my decisions. & 0.578 \\
\hline It helps me understand the concepts I've studied. & 0.772 \\
\hline \multicolumn{2}{|c|}{ Development of the critical thought experience (Cronbach's alpha $=0.71$ ) } \\
\hline I am sure that I can reach a reasonable conclusion. & 0.593 \\
\hline It is important to be well informed. & 0.711 \\
\hline I listen carefully to the opinions of others. & 0.533 \\
\hline I look for opportunities to solve problems. & 0.730 \\
\hline I ask myself a lot of questions during the learning process. & 0.576 \\
\hline I think most problems have more than one solution. & 0.564 \\
\hline I am capable of explaining things clearly. & 0.512 \\
\hline I can change my mind when I receive new information. & 0.593 \\
\hline I present problems clearly and precisely. & 0.713 \\
\hline
\end{tabular}

Table 2. Rotated component matrix of the factor analysis

In terms of the experience, the enthusiasm and interest shown by the students can be stressed from the very first moment. The simulation created high expectations for the results, and the students felt very motivated throughout the activity.

\section{Evaluation of the experience}

As can be seen in Table 3, the activity was considered to be pleasant and provided a positive experience for the students, with mean values greater than 3.17 out of 5 . The highest value observed refers to "I have been completely concentrated" (4.41) and the lowest value refers to "The tasks were challenging for me" (3.17). These results demonstrate that the experience by the players has been effective, not only because it was entertaining for them, but also because it ensured student concentration, as it was conducted at an appropriate pace and the challenges were appropriate in terms of their knowledge level, so that they learned without feeling overwhelmed by the difficulty of the tests. 
Since the simulation has an interface that permits communication between the participants and the program, the menus and windows are easy to read and understand, and thanks to this, it held the students' interest (Curry \& Moutinho, 1992).

\begin{tabular}{|l|r|r|}
\hline \multicolumn{1}{|c|}{ Items } & \multicolumn{1}{|c|}{ Mean } & \multicolumn{1}{|c|}{$\begin{array}{l}\text { Standard } \\
\text { deviation }\end{array}$} \\
\hline I have been completely concentrated on the simulation. & 4.41 & 0.497 \\
\hline The simulation captured my attention from the very beginning. & 4.40 & 0.493 \\
\hline I would recommend this activity to my classmates. & 4.07 & 0.684 \\
\hline The simulation moved along at the right pace. & 3.96 & 0.745 \\
\hline The contents are connected to other knowledge I already had. & 3.63 & 1.040 \\
\hline The tasks are not too easy or too difficult; they pose a challenge to me. & 3.34 & 0.822 \\
\hline I was convinced that I was learning. & 3.34 & 0.711 \\
\hline It is easy to understand and to use. & 3.17 & 0.853 \\
\hline
\end{tabular}

Table 3. Results obtained with regard to the evaluation of the experience

\section{Learning: Active learning and cognitive benefits derived from the simulation}

The result of the learning achieved based on the incorporation of the simulation in the classroom has been measured from two perspectives. The first evaluates the perception the students have of their participation in the educational process, thanks to the use of simulations. In order for active learning to occur, students must do much more than simply listen; they must read, ask questions, engage in discussions, solve problems, etc., i.e., they must be attentive and constantly involved in the work. In this way, students are no longer spectators and take on greater commitment and thus learn to recognize how much information they need and when.

Students have the perception that their learning is active with the simulations, as shown in Table 4. They value being able to participate in their training (4.55), controlling their own learning (3.75), since they can set the pace at which they learn (3.47).

The second perspective measures the cognitive benefits derived from the use of the simulations (Antonietti et al., 2000 and Lee et al., 2010). The results are presented in Table 5, and show that the activity has favored the memorization process (4.50), and since it gives them a more global view of the company (4.13) and enables them to reflect on the consequences of the decisions they make (4.12), it facilitates the comprehension of the topics studied in the lectures. These results coincide with those obtained by authors such as Escobar and Lobo (2005), Pasin and Giroux (2011) and Romero and Turpo (2012), who observe that when students learn accounting concepts using simulations as a 
teaching methodology, they develop an improved capacity for analysis and gain a better view of reality. It has thus been demonstrated that they are effective when students must develop skills related to decision-making in complex and dynamic situations.

\begin{tabular}{|l|r|r|}
\hline \multicolumn{1}{|c|}{ Items } & \multicolumn{1}{|c|}{ Mean } & \multicolumn{1}{c|}{$\begin{array}{l}\text { Standard } \\
\text { deviation }\end{array}$} \\
\hline It allows me to be more perceptive and active in my learning process. & 4.55 & 0.502 \\
\hline I can have more control over my own learning. & 3.75 & 0.750 \\
\hline I can learn at my own pace. & 3.47 & 1.150 \\
\hline
\end{tabular}

Table 4. Results obtained in relation to active learning during the simulation

\begin{tabular}{|l|r|r|}
\hline \multicolumn{1}{|c|}{ Items } & \multicolumn{1}{|c|}{ Mean } & \multicolumn{1}{|c|}{$\begin{array}{l}\text { Standard } \\
\text { deviation }\end{array}$} \\
\hline The simulation boosts my memorization process. & 4.50 & 0.823 \\
\hline The simulation helps give me an overview of the company. & 4.13 & 0.854 \\
\hline The activity lets me reflect on the consequences of my decisions. & 4.12 & 0.577 \\
\hline The simulation helps me better understand the concepts I've studied. & 3.65 & 0.654 \\
\hline
\end{tabular}

Table 5. Cognitive benefits derived from the simulation

\section{Critical thinking}

Thanks to the business simulation and later classroom discussion sessions dealing with strategies, both winning and losing, the students acknowledge having experienced cognitive gains, specifically in areas related to critical thinking, problem solving and decision-making. The students perceive that a problem may have multiple perspectives and they indicated that during the debates held during the simulation or afterwards, they became aware of the existence of more than one legitimate point of view.

The students' improvement in critical thinking helps develop their problem solving capacity. For this reason, they were able to use different theoretical frameworks to analyze the matters, enabling them to see and articulate the problem in different contexts (for example, in human resources, financial and marketing contexts).

All the scores presented in Table 6 are high, especially in the case of "I am sure that I can reach a reasonable conclusion" (4.51), but obviously, this will be better with the "improved information available" (4.51).The students positively value "the opinion of the rest of the participants, even when it does not match mine" (4.12), and are not satisfied with the first solution they find, as they recognize that "I look for new opportunities for problem solving" (3.99) "asking many questions in the learning 
process" (3.98), "since most problems have more than one solution" (3.84). The skill they perceive to be the least developed is that related to presenting problems in a clear and precise manner (3.13), but this is a skill that is usually gradually acquired with practice and this was the first time that they participated in this type of activity.

\begin{tabular}{|l|r|r|}
\hline \multicolumn{1}{|c|}{ Items } & \multicolumn{1}{|c|}{ Mean } & \multicolumn{1}{c|}{$\begin{array}{c}\text { Standard } \\
\text { deviation }\end{array}$} \\
\hline I am sure that I can reach a reasonable conclusion. & 4.51 & 0.732 \\
\hline It is important to be well informed. & 4.51 & 0.823 \\
\hline $\begin{array}{l}\text { I listen carefully to the opinions of others, even when they do not agree } \\
\text { with me. }\end{array}$ & 4.12 & 0.854 \\
\hline I look for opportunities to solve problems. & 3.99 & 0.678 \\
\hline I ask myself a lot of questions during the learning process. & 3.84 & 1.264 \\
\hline I think most problems have more than one solution. & 3.63 & 1.437 \\
\hline I am capable of explaining things clearly. & 3.51 & 0.819 \\
\hline $\begin{array}{l}\text { I can change my mind when I receive new information that conflicts } \\
\text { with my current opinion. }\end{array}$ & 3.13 & 0.734 \\
\hline I present problems clearly and precisely. & & 0.711 \\
\hline
\end{tabular}

Table 6. Results obtained with regard to the development of critical thinking

\section{Conclusions}

The results obtained in this study confirm that students are accustomed to using information and communication technologies. Due to their immersion in this culture, they have developed new cognitive skills and learning styles. For them, learning is more closely linked to processes of trial and error than to logical procedures.

The dimensionality of the model has revealed a four-factor structure, as gathered from the literature review. Because of this, business simulations are an educational tool in which students positively value the experience, actively participate in their own learning and have the perception that they are learning to solve problems by accessing varied information in order to make decisions based on its evaluation.

Focusing on this experience, it has been assessed as pleasant and fun, has promoted cooperation and/or competition, requiring students to remain concentrated throughout the entire activity, thanks to which they have positively assessed the pace with which the simulation was conducted and are satisfied in this regard, and would recommend it to their classmates. The business simulation has thus provided a positive experience for the students. 
By having captured the attention of the students and awakened their interest in the topics presented, they state that the use of simulations increases the attractiveness of the course. Said tool requires students to build their own knowledge, since they must ask questions, generate and explore their own models and support the representations that organize their experiences, instead of inheriting these from the words of an instructor. All of this makes this a methodology that increases their motivation to learn.

Given that they have had to analyze a situation focused on a competitive environment, the students have been able to consolidate knowledge, developing their skills, abilities and competencies, since based on the recreation of scenarios adapted from real life, they have had to solve problems related to decision-making in an environment of uncertainty.

Because of this, students perceive these simulations as useful tools that facilitate the acquisition of competencies, among which we might stress the power to search for, organize, retrieve and manage information, facilitating critical thinking.

The increase in the information students have when engaging in group discussions in which they explain the tactics used promotes the generation of new ideas and positions analyzed from different angles. The intent to base their decisions solely on true premises is no longer an option for them, since they are now capable of formulating questions and solving problems in a way that is clearer and more precise, gathering and evaluating information effectively and using it to propose well-reasoned solutions.

Therefore, the results obtained allow us to confirm that business simulations are instruments that facilitate learning, without this meaning that they replace the techniques used before now; quite the opposite, they are complementary to them, contributing in a substantial manner to their influence on the intermediate variables that are crucial for learning, such as motivation and concentration.

\section{References}

Association to Advance Collegiate Schools of Business (2007). Available online at: http://www.aacsb.edu/ (Last access date: February 2nd, 2016).

Andreu-Andreu, M.A. \& García-Casas, M. (2014). Evaluación del pensamiento crítico en el trabajo en grupo. Revista de Investigación Educativa, 32(1), 203-222. 
Annetta, L., Minogue, J., Holmes, S., \& Chen, M-T. (2009). Investigating the impact of video games on high school students' engagement and learning about genetics. Computers \& Education, 3, 74-85. https://doi.org/10.1016/j.compedu.2008.12.020

Antonietti, A., Rasi, C., Imperio, E., \& Sacco, M. (2000). The representation of virtual reality in education. Education and Information Technologies, 5(4), 317-327. https://doi.org/10.1023/A:1012057608694

Arellano, F., Hine, S., \& Thilmany, D.D. (2001). Using MANECSIM as a simulation for agribusiness capstone courses. Review of Agricultural Economics, 23(1), 275-285. https://doi.org/10.1111/1058-7195.00060

Armstrong, S.J., \& Hird, A. (2009). Cognitive style and entrepreneurial drive of new and mature business owner-managers. Journal of Business \& Psychology, 24, 429-430. https://doi.org/10.1007/s10869009-9114-4

Axerol, R. (2006). Advancing the art of simulation in the social sciences. In J. Rennard, (Ed.), Handbook of research on nature-inspired computing for economics and management. Hersey, PA: Idea group reference.

Bell, R., \& Loon, M. (2015). The Impact of Critical Thinking Disposition on Learning using Business Simulations. International Journal of Management Education, 13(2), 119-127. https://doi.org/10.1016/j.ijme.2015.01.002

Blunt, R. (2009). Do Serious Games Work? Results from Three Studies. eLearn Magazine ACM. Available online at: http://elearnmag.acm.org/featured.cfm?aid=1661378 https://doi.org/10.1145/1661377.1661378

Bontis, N. (1998). Intellectual Capital: An exploratory study that develops measures and models. Management Decision, 36(2): 63-76. https://doi.org/10.1108/00251749810204142

Bratley, P., Fox, B., \& Schrage, L. (1987). A guide to simulation (Second ed.). Springer-Verlag (New York). https://doi.org/10.1007/978-1-4419-8724-2

Chin, W.W., \& Marcolin, B. (1995). The holistic approach to construct validation in IS research: Examples of the interplay between theory and measurement, en Compeau, D. (ed.). ASAC-23 Conference, IS Proceedings. 16(4), 33-43.

Córdova, D.I., \& Lepper, M.R. (1996). Intrinsic motivation and the process of learning: Beneficial effects of contextualization, personalization, and choice. Journal of Educational Psychology, 88(4), 715-730. https://doi.org/10.1037/0022-0663.88.4.715

Curry, B., \& Moutinho, L. (1992). Using Computer Simulations in Management Education. Management Education and Development, 23(2), 155-167. https://doi.org/10.1177/135050769202300212 
Durham Y., \& Mckinnon, T. (2006). Classroom experiments: not just fun and games. Economic Inquiry, 45(1), 162-178. https://doi.org/10.1111/j.1465-7295.2006.00003.x

Escobar Pérez, B., \& Lobo Gallardo, A. (2005). Juegos de simulación empresarial como herramienta docente para la adaptación al espacio europeo de educación superior: Expriencia en la diplomatura en turismo. Cuardenos de Turismo, 16, 85-104.

Fitó-Bertran, A., Hernández-Lara, A.B., \& Serradell-López, E. (2014). Comparing student competences in a face-to-face and online business game. Computers in Human Behavior, 30, 452-459. Available online at: http://www.sciencedirect.com/science/article/pii/S074756321300215X https://doi.org/10.1016/j.chb.2013.06.023

Freitas, S. de, \& Jarvis, S. (2007). Serious Games - Engaging Training Solutions: A research and development project for supporting training needs. British Journal of Educational Technology, 8(3), 523-552. https://doi.org/10.1111/j.1467-8535.2007.00716.x

Garris, R., Ahlers, R., \& Driskell, J. (2002). Games, Motivation, and Learning: A Research and Practice Model. Simulation and Gaming, 33(4), 441-467. https://doi.org/10.1177/1046878102238607

Gresse von Wangenheim, C., Savi, R., \& Ferreti Borgatto, A. (2012). DELIVER! An educational game for teaching Earned Value Management in computing courses. Information and software Technology, 54(3), 286-298. https://doi.org/10.1016/j.infsof.2011.10.005

Guillén-Nieto, V., \& Aleson-Carbonell, M. (2012). Serious games and learning effectiveness: The case of It's a Deal!. Computers \& Education, 58(1),435-448. https://doi.org/10.1016/j.compedu.2011.07.015

Halpern, D.F. (1996). Thought and knowledge: An introduction to critical thinking. Mahwah, NJ: Lawrence Erlbaum.

Hamari J., Shernoff, D.J., Rowe, E., Coller, B., Clarke, J.A., \& Edwards, T. (2016). Challenging games help students learn: An empirical study on engagement, flow and immersion in game-based learning. Computers in Human Behavior, 54(2016), 170-179. https://doi.org/10.1016/j.chb.2015.07.045

Huang, W.H. (2011). Learners' motivational processing and mental effort investmentin an online gamebased learning environment: A preliminary analysis. Computersin Human Behavior, 27, 694-704. https://doi.org/10.1016/j.chb.2010.07.021

Irani, T., Rudd, R., Gallo, M., Ricketts, J., Friedel, C., \& Rhoades, E. (2007). Critical Thinking Instrumentation Manual. Gainesville, FL.: University of Florida. Available online at: http://step.ufl.edu/ resources/critical thinking/ctmanual.pdf

Joint Quality Initiative (2004). European Higher Education Area. Bologna Process. Available online at: http://archive.ehea.info/folder?year selected=4\&issued by=349 (Last access date: January 20th, 2015). 
Keys, B., \& Wolfe, J. (1990). The role of management games and simulations in education and research. Journal of management, 16(2), 307-336. https://doi.org/10.1177/014920639001600205

Kennedy, M., Fisher, M.B., \& Ennis, R.H. (1991). Critical thinking: Literature review and needed research. In L. Idol \& B. F. Jones (Eds.), Educational values and cognitive instruction: Implications for reform. Hillsdale, Nueva Jersey: LEA.

Lee, EA-L., Wong, K.W., \& Fung, C.C. (2010). How does desktop virtual reality enhance learning outcomes? A structural equation modeling approach. Computers \& Education, 55, 1424-1442. https://doi.org/10.1016/j.compedu.2010.06.006

Martínez-Argüelles, M.J., Plana, D., Hintzmann, C., Batalla Busquets, J.M., \& Badia, M. (2015). Usefulness of feedback in e-learning from the students' perspective. Intangible Capital, 11(4), 627-645. https://doi.org/10.3926/ic.622

Mayer, R.E., \& Johnson, C.I. (2010). Adding instructional features that promote learning in a game-like environment. Journal of Educational Computing Research, 42(3), 241-265. https://doi.org/10.2190/EC.42.3.a

Moizer, J., Lean, J., \& Towler, M. (2009). Simulations and games overcoming the barriers to their use in higher education. Active Learning in Higher Education, 10(3), 207-224. https://doi.org/10.1177/1469787409343188

Nunally, J.C., \& Bernstein, I.H. (1994). Psychometric Theory. New York. McGraw Hill.

Pasin, F., \& Giroux, H. (2011). The impact of a simulation game on operations management education. Computers \& Education, 57(1), 1240-1254. https://doi.org/10.1016/j.compedu.2010.12.006

Pekrun, R., Goetz, T., Daniels, L.M., Stupnisky, R.H., \& Perry, R.P. (2010). Boredom in achievement settings: Exploring control-value antecedents and performance outcomes of a neglected emotion. Journal of Educational Psychology, 102(3), 531-549. https://doi.org/10.1037/a0019243

Romero, M., \& Turpo G.O. (2012). Serious Games para el desarrollo de las competencias del siglo XXI. RED. Revista de educación a distancia, 34. Available online at: http://www.um.es/ead/red/34/

Shannon, R., \& Johannes, J. (1976). Systems Simulation: The art and Science. Systems, man and ciybernetics, SMC, 6(10), 723-724. https://doi.org/10.1109/TSMC.1976.4309432

Sitzmann, T. (2011). A meta-analytic examination of the instructional effectiveness of computer-based simulation games. Personnel Psychology, 64(2), 489-528. https://doi.org/10.1111/j.1744-6570.2011.01190.x

Sørensen, M. (2010). Learning with simulation games. Evaluating Hotel Simulation Games' Efectiveness on Higher Academic Performance within Service and Hospitality. Copenhagen Business School: Handelhøjskolen. 
Sterman, J. (2014). Interactive web-based simulations for strategy and sustainability: The MIT Sloan Learning Edge management flight simulators, part I. System Dynamics Review, 30, 89-121. https://doi.org/10.1002/sdr.1513

Sutcliffe, M. (2002). Games, simulations and role playing: The handbook for economics lecturers. Bristol, UK: Economics LTSN.

Urquidi Martín, A.C., \& Calabor Prieto, M.S. (2014). Aprendizaje a través de juegos de simulación: Un estudio de los factores que determinan su eficacia pedagógica. Edutec-e. Revista electrónica de tecnología educativa, 47, Abril 2014. Available online at: http://www.edutec.es/revista/index.php/edutec-e/article/view/75

Witkin, H.A., Moore, C.A., Oltman, P.K., Goodenough, D.R., et al. (1977). Role of the field dependent and field independent cognitive styles in academic evolution: A longitudinal study. Journal of Educational Psychology, 69 (3), 197-211. https://doi.org/10.1037/0022-0663.69.3.197

Wouters, P., Van Mimwegen, C., Van Oostendorp, H., \& Van der Spek, E. (2013). A Meta-Analysis of the Cognitive and Motivational Effects of Serious Games. Journal of Educational Psychology, 105 (2), 249-265. https://doi.org/10.1037/a0031311

Wrzesien, M., \& Alcañiz Raya, M. (2010). Learning in serious virtual worlds: Evaluation of learning effectiveness and appeal to students in the E-Junior project. Computers \& Education, 55 (1), 178-187. https://doi.org/10.1016/j.compedu.2010.01.003

Yusoff, A., Crowder, R., \& Gilbert, L. (2010). Validation of serious games attributes using the technology acceptance model. 2nd international Conference on games and virtual worlds for serious applications. Braga, Portugal. https://doi.org/10.1109/VS-GAMES.2010.7

Intangible Capital, 2017 (www.intangiblecapital.org)

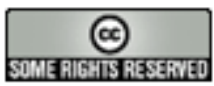

Article's contents are provided on an Attribution-Non Commercial 3.0 Creative commons license. Readers are allowed to copy, distribute and communicate article's contents, provided the author's and Intangible Capital's names are included. It must not be used for commercial purposes. To see the complete license contents, please visit http://creativecommons.org/licenses/by-nc/3.0/. 